\title{
Relocation and Agglomeration of Chinese Industry
}

\author{
Mei Wen \\ Australian National University
}

August 2001

\begin{abstract}
This paper investigates spatial concentration of Chinese manufacturing using the data collected in both the second and third national industrial censuses. It is found that many of China's manufacturing industries were highly geographically concentrated in several coastal regions in 1995. A historical comparison of the concentration levels between 1980, 1985 and 1995, suggests that manufacturing industries have become more geographically concentrated following the economic reform. Results from production function estimation and further regressions suggest that the industrial agglomeration in China is driven by both transaction agglomeration and production agglomeration based on increasing returns to scale effect.
\end{abstract}

Key Words: Industrial concentration, transportation cost, preferential development policies, the extent of the market, foreign investment, trade barriers.

JEL Classification: L60, R10, O18.

Acknowledgement: The author is grateful to Mary Amiti, Prema-chandra Athukorala, and Peter Lloyd for helpful comments. Editorial help from Carol Kavanagh is highly appreciated.

\footnotetext{
* Address of correspondence: Mei Wen, Division of Economics, RSPAS, Australia National University, Canberra, ACT0200, Australia. Email: rosemei.wen@anu.edu.au
} 


\section{Relocation and Agglomeration of Chinese Industry}

\section{Introduction}

Location of firms and the geographical distribution of industry have significance for economic efficiency. While models enlightened by von Thünnen play a very important role in urban studies and Hotelling-type models are frequently used for describing locational competition in industrial organization, since Krugman (1991), more and more theoretical models have been developed to explain the economic rationale of geographical concentration or dispersion of industries.

When production technology exhibits increasing returns to scale, the geographical concentration of firms in places where there is a large population reduces the average cost of production due to the large size of the market. The cheaper produce and increased real income enlarges the market, as the size of the market is not the size of population alone, instead, it is the purchasing power. When transportation costs are incurred between purchase and consumption of a good, geographical proximity to trade partners saves transportation costs regardless of production technology. If people (trade partners) choose to live close to one another in order to save transaction and transportation costs, this can be called transaction agglomeration. Manufacturing firms in each industry may concentrate in a few regions, due either to increasing return to scale technology or to economies of transaction agglomeration. When many manufacturing industries concentrate in the same region or in several nearby regions, there is production agglomeration. Therefore, whenever the economies of production agglomeration have not yet caused a large increase in wage rates and the economies of transaction agglomeration have not pushed up rents to a very high level, people and firms in footloose industries will migrate into the region to save transportation costs. In addition, if there is a preference for consumption variety, and final goods are differentiated substitutes, there will be a greater variety of products in the region. Without migration, or when increased rent outweighs the benefit of living in the region, increased labour demand will significantly bid up wages, thus substantially increasing production costs. 
With improvement in the transportation system and reduction of transportation costs to lower levels, cheaper labour and rent in other regions will induce firms to disperse to those other regions ${ }^{\square}$.

Before 1949, as a consequence of historic events and economic choices, many Chinese manufacturing firms were located in coastal regions. However, from 1953 to 1978, the location of Chinese industrial firms was not determined by economic concerns. Instead, concern about destruction from potential military conflicts led to the strategic location of industrial firms towards inland China. From 1965 to 1978 in particular, large industrial firms were located according to the following three principles: geographical proximity to mountains, dispersion, and concealment. As the transportation system in inland China and mountainous regions was not efficient, these three principles are obviously contrary to the economic principles of industrial location discussed above. Many economists would be astonished by the principles guiding China's industrial location prior to the economic reform and may wonder about the geographical location of Chinese industry after more than two decades of market-oriented economic reforms.

This paper examines the relocation and agglomeration of Chinese manufacturing from 1980 to 1995 , using data from the second and the third national industrial censuses. Following the economic reforms, priority given to the development of eastern coastal China and the early establishment of special economic zones in southern coastal China have changed the geographical distribution of Chinese manufacturing substantially. From the old geographical distribution to a new spatial location with agglomeration, how Chinese industries have been gradually relocating and concentrating with economic forces and relevant policies is a key issue to understanding China's industrialization, the future perspective for Chinese industries, and its regional development. But to what extent Chinese manufacturing industries have become more concentrated and to where

\footnotetext{
${ }^{1}$ This kind of linkage modelling between prices of products, prices of factors, total transportation costs per person incurred for his/her consumption, prices of housing and per capita real income in the region have been gradually developed from a model with only final goods with labour mobility (Krugman 1991), a model with differentiated products (Fujita and Krugman 1995), a model with input-output vertical linkage (Krugman and Venable 1995), a model with multi-region and multi-indsutry (Puga and Venable 1996), to a model with land market (Tabuchi 1998).
} 
they have re-concentrated has not been fully analysed. Young (1997) observed regional convergence in industrial production structure and pointed out that high inter-regional trade barriers obstruct regional industrial specialization and division of labour. However, the focus of this paper is not the comparison of industrial production structure among regions, but to investigate what factors contributed to the agglomeration and relocalization of Chinese manufacturing. The paper is organized as follows. Section 2 first looks at 3-digit industrial locational Gini in 1995, to see whether large and medium sized manufacturing firms are concentrated in certain regions. Section 3 provides a historical comparison, based on the degrees of 2-digit industrial concentration (including all industrial firms) and analyses how Chinese manufacturing is re-located and concentrated. The factors contributing to manufacturing relocation and agglomeration are analysed in Section 4. Section 5 discusses the implications of the present industrial geographical distribution for further industrial and regional development, and concludes the paper.

\section{Geographical concentration of large and medium sized manufacturers}

This section attempts to paint a picture of the spatial distribution of large and medium sized manufacturers to see whether their geographical locations reflect any economic rationale. Questions such as whether Chinese industry has become more or less concentrated after the economic reform and what forces drive Chinese industrial relocation and concentration will be addressed in later sections.

With the rapid development of non-state owned enterprises, the number of industrial enterprises in China grew dramatically, from 5.19 million units in 1985 to 10.02 million units in 1995. Meanwhile, the share of large and medium sized enterprises ${ }^{\text {}}$ in total output value decreased from about 50 per cent in 1985 to 36 per cent in 1995 . However, large and medium sized firms are usually given special attention and preferential treatment by both central and local governments, as they are major contributors to government revenues. Due to the advantage in getting financial resources and in

\footnotetext{
${ }^{2}$ The definition of large and medium sized firms varies from industry to industry. See China Statistical Yearbook of Industrial Economy for the definition.
} 
technology upgrading, the geographical location of large and medium sized firms has very important implications for the spatial distribution of the whole industry, as they would pull upstream or downstream firms to locate nearby in order to save on the transportation costs of intermediate inputs.

To assess the degree of geographical concentration, the provinces are adopted as regions and Gini coefficients are calculated for each 3-digit manufacturing industry. Industrial locational Gini is a common measure of geographical concentration ${ }^{4}$. A Gini coefficient for each industry $i$ is calculated as follows:

$$
G_{i}=\frac{1}{2 n^{2}} \overline{s_{i}} \sum_{k=1}^{n} \sum_{j=1}^{n}\left|s_{i j}-s_{i k}\right|
$$

where $s_{i j}$ is the share of industry $i$ in province $j, s_{i k}$ is the share of industry $i$ in province $k$, $n$ is the number of provinces and $\overline{s_{i}}$ is the mean of shares. The industry Gini coefficient is equal to twice the area between a 45-degree line and a Lorenz curve. For each industry $i$, the Lorenz curve is derived by ranking $s_{i j}$ in descending order and plotting its cumulative on the vertical axis against the cumulative of the number of provinces on the horizontal axis (with each interval having the same width, equal to $1 / \mathrm{n}$ ). The closer the distribution of industry $i$ to a uniform distribution, the smaller the index. If an industry is equally distributed across all provinces the index will equal zero. An index close to one suggests that an industry is entirely concentrated in a province 5 .

Industry Gini coefficients are constructed using value added data from the Third National Industrial Census conducted in $1995^{6}$. There are different views as to whether valueadded or gross output value should be used in the calculation of the industrial Gini coefficient. Those who favour value added argue that it provides a better indication of the

\footnotetext{
${ }^{3}$ A region can be defined at county, city or provincial level. Due to limited availability of data, a province is used as a region in this paper although analysis at city or county levels might be desirable.

${ }_{5}^{4}$ See Amiti (1998) for a survey.

${ }^{5}$ The maximum value the Gini can take is $(\mathrm{n}-1) / \mathrm{n}$.

${ }^{6}$ The Third Industrial Census includes 6416 large enterprises and 16591 medium enterprises. All the single unit records enterprises in the survey are independent accounting industrial enterprises at and above township level with sales revenue of at least one million yuan. There are 23026 observations in the database that has total value added of 947.91 billion yuan. Some observations either had missing values or negative value added, or could not be mapped to a province. After deleting these observations, there are 20667 observations left in the sample. This makes up 36 per cent of total manufacturing.
} 
size of an industry $i$ in province $j$ than gross output, because a part of gross output value may be imported from another province. However, those who favour gross output value argue that it is a better measure of the regional industrial size when the spatial location issue is considered, as the intermediate inputs involve transportation costs and firms' location decisions are usually based on the plant size which can be better measured by gross output value. Both arguments are sensible. While I prefer to use value-added in the calculation of locational Gini and gross industrial output value in analyzing what determines industrial location, what I shall use in the calculation of industrial locational Gini will depend on data availability. In the calculation of the 3-digit industrial Gini coefficient, value added at current prices is used.

Calculated industry locational Gini coefficients, ranked in descending order, are reported in Table 1. The results indicate that large and medium sized manufacturing firms are highly localised. Nearly all of the industries recorded a Gini coefficient greater than 0.50, with one third of them over 0.80 . The second column indicates which province produced the highest share of industry $i$ and the last column indicates whether the province is in the coastal region. As expected, the coastal provinces produce the largest share of value added in most industries. A number of interesting points emerge from Table 2.

First, some of the highly localised industries appear to be natural resource and land intensive. These include artificial crude oil (251) concentrated in the province of Shanxi; salt processing (136) in Jiling; precious metal smelting (333) and iron smelting (321) in Hebei, nonferrous metal alloy smelting (336) in Hunan, and primary processing of raw fibre materials (171) and baking of tobacco leaves (161) in Shandong. If the natural resources or inputs required in these industries are endowed or planted only in limited regions, and the industries are concentrated in these limited regions, the geographical distribution of these industries should be consistent with the predictions of a standard Heckscher-Ohlin model, as the region where the production localizes has a comparative advantage in resource endowment. 
Second, many of the relatively "footloose" industries are concentrated in coastal regions. Footloose industries are not tied to any particular location due to the need for natural resources, and can be quickly viable once they move to a new location as they are not both capital and skill intensive. It can be seen from Table 1 that most industries recording a Gini coefficient above 0.75 are concentrated in coastal regions. Except for those resource-based industries discussed in the first point, and some capital and skill intensive industries, most of the remaining industries are relatively footloose. If the coastal regions are large domestic markets in terms of purchasing power and as they are close to ports for export, the agglomeration of these footloose industries can be driven by agglomeration of transactions for saving transportation or transaction costs no matter whether there are increasing returns to scale in production. Furthermore, if the technology presents increasing returns to scale, the industries with increasing returns to scale technology would locate in the coastal regions to take advantage of longer production runs from generating the so called "home market" effect ${ }^{\square}$. Hence, when increases in wages and rents are not substantial, compared with savings in transportation or transaction costs, proximity to trade partners can be a force for agglomeration. Increasing returns to scale in production would also be an agglomeration force. Further evidence is needed to see whether these two forces drive the agglomeration, and thus will be provided in section 4 .

It cannot be ascertained from Table 1 why many of these non-resource based industries are concentrated in Guangdong province while many others are concentrated in Shanghai city, and Zhejiang, Shandong and Jiangsu provinces. For example, why bamboo, cane, palm fibre and straw products (204) and furniture (212), game equipment (245), record pressing (232), plastic bags, packages and containers (305), medical equipment (365), fishing equipment and fishing materials (285), and soft drinks (152), are all clustered in Guangdong province? Whereas, cultural goods (241), machines for cultural and office usage (425), synthetic fibre (282), and clocks (426) are localized in Shanghai; tea baking (155), wood products (203) and silk textiles (177) are concentrated in Zhejiang; other tobacco processing (169) and handcraft and arts (431) are located in Shandong; other fibre products (189), other instruments and meters (429), and other textile (179) are

\footnotetext{
${ }^{7}$ See Amiti and Wen (forthcoming) for explanations.
} 
concentrated in Jiangsu? Without a retrospect of the development history of Chinese industries and knowledge of regional industry comparative advantage in technology, it is not possible to distinguish the locational difference in this industrial agglomeration.

Third, most of those geographically dispersed industries which recorded a Gini coefficient lower than 0.58 produce high transport cost goods, such as metal processing machinery (352), grain and forage processing (131), cement manufacturing (311), printing (231), cotton textiles (172), and chemical fertilizer (262). By locating close to final consumers across China, firms in these industries save on transport costs.

\section{A Historical Comparison}

It can be seen from Table 1 that in 1995 the large and medium sized firms of 3-digit industries are highly geographically concentrated. However, without a historical comparison, it is impossible to get a picture of the extent of industrial concentration following the economic reform and how industries have been relocating from former industrial bases to new industrial cores.

When the People's Republic of China was established in 1949, Chinese industry was highly geographically concentrated (DRCSC, 1992). Due to the impact of Japanese occupation of the Eastern Liaoning Peninsula and the effect of leasing territories to foreigners in Shanghai, 70 per cent of industry was then localized in China's eastern coastal belt which occupied less than 12 per cent of national land. Among all these industries, heavy industries were concentrated in the middle part of Liaoning province while light industries such as textiles and repair of machinery, were localized in Shanghai, Wuxi, Tianjing, and Qingdao cities. However, the inland development policies adopted in the first five-year plan period attempted to balance regional development by establishing close to two thirds of all new industrial projects in inland China. Later, the three strategic principles guiding the location of industrial firms, together with duplication of production among provinces for self-sufficiency $\mathrm{Q}_{\text {substantially changed }}$

\footnotetext{
${ }^{8}$ See Young (1997) for reports on duplication of production structure among provinces.
} 
China's industrial location. By 1980, many 2-digit manufacturing industries were distributed among Shanghai, Jiangsu, Liaoning, Shandong, Heilongjiang, Beijing, Hubei, Henan, Sichuan and Shannxi provinces.

Due to lack of data on the value added of manufacturing industries in 1980 and 1985 and to many changes in industrial classifications, gross output value is used to calculate industrial locational Gini and the locational Gini coefficients of 25 time-consistently classified 2-digit manufacturing industries are presented in Table 2. In Table 2, GINI95, GINI85, GINI80 are the locational Gini coefficients of 1995, 1985 and 1980, respectively. RHSH95, RHSH85 and RHSH80 label the regions with the highest share and the second highest share in order in the gross industrial output value of the years 1995, 1985, and 1980, respectively. The data for 1980 and 1985 are drawn from the second national industrial census (LBNICSC, 1986) and the data for 1995 are drawn from the third national industrial census (TNICO, 1997). From Table 2, the following observations are obtained.

First, during 1980 to 1995 , twenty-two of the twenty-five industries became more geographically concentrated. The Gini coefficients of these twenty two industries increased on average by 21 per cent with the highest increase in industry 19-leather, fur, feather and manufacturing of leather, fur and feather products, which recorded a 64 per cent increase. In 1995, most industries were highly concentrated in Guangdong and Jiangsu provinces. Second, two manufacturing industries-smelting and pressing of ferrous metal and smelting and pressing of nonferrous metal—became geographically dispersed. The locational Gini of these two industries declined by 9 per cent and 19 per cent, respectively. One industry - the chemical fiber industry — was less concentrated in 1995 than it was in 1980. Its locational Gini decreased from 0.72 in 1980 to 0.67 in 1985, then rose back to only 0.68 by 1995 . Third, among those twenty-two more geographically concentrated industries, nine became more concentrated consecutively from 1980 to 1985, and from 1985 to 1995 . However, the other thirteen industries experienced dispersion to different extent from 1980 to 1985 , then concentration to a higher degree from 1985 to 1995 . Some of these 13 industries involve re-localization in 
the dispersion-concentration process. Fourth, except for the industry 12-logging and transport of wood and bamboo, the other eight 2-digit industries that experienced consecutive concentrations are industries mainly producing final consumption goods, and have many new products produced with new technologies. Fifth, from the results shown in RHSH95, RHSH85 and RHSH80, it can immediately be seen that by 1995 Guangdong province replaced Shanghai city as the core location for manufacturing industries, although some manufacturing industries are still highly localized in Shanghai. Furthermore, more industries were concentrated in fewer and geographically closer regions in 1995, indicating industrial agglomeration.

From Tables 1 and 2, it can be seen that, on average, in 1995 the 3-digit industries recorded a Gini coefficient much higher than those for the 2-digit industries. This can mainly be due to two reasons: (1) only large and medium sized firms are counted in the Gini calculation in Table 1 while the calculation of 2-digit industrial Gini includes all firms in the industry; (2) Within each 2 digit industry, different regions may have comparative advantage in different sub-3-digit industries, so that 3-digit industries would be more concentrated in certain regions ${ }^{2}$.

\section{Determinants of the Localization and Agglomeration of Chinese Industry}

The results reported in the previous sections suggest the spatial location of Chinese manufacturing has changed substantially, with higher degrees of geographical concentration for many manufacturing industries and the relocation of some. To some extent, the location of manufacturers has changed from an issue of war-preparedness to an economic choice. As a result of the economic reform, the relocation of industries reflects the industrial development policies adopted during the economic reform period.

\footnotetext{
${ }^{9}$ The fact that value added is used to calculate the 3 -digit industrial Gini while gross industrial output value has to be used to calculate the 2-digit industrial Gini, due to the limitation of data availability, could also cause the difference, but the effect should not be large.
} 
Economic Reform, Regional Comparative Advantage and Localization of Industries

In contrast to the agricultural reforms implemented countrywide at about the same time, industrial reform in China gave priority to coastal regions by establishing four special economic zones (SEZs hereafter) in Guangdong and Fujian provinces in 1980. The aim of this regional emphasis was to benefit from the geographical advantage of the coastal regions in accessing the world market and in attracting foreign capital in order to first develop these regions, and then generate a radiation effect to other regions, so as to develop the middle and western regions sequentially. In the SEZs, special privileges, such as the right to import intermediate inputs duty free, were granted to exporting firms. As a consequence, these SEZs first attracted foreign investment. In 1987-88, the adoption of the Coastal Development Strategy further promoted an export-oriented sector, and more foreign investment was attracted to the four SEZs and fourteen open coastal cities. Meanwhile, domestic industrial investment also tended to be high in the coastal regions because of fiscal decentralization. Subsequently, the regional share in total industrial output value of Guangdong province, Shanghai city, and Jiangsu, Zhejiang and Shandong provinces increased to a large extent from 1980 to 1995, where the regional share in industry of Guangdong province increased by 7.4 per cent ${ }^{10}$. The share in total industrial output value of most other regions declined during the same period, with Gansu, Sichuan, Shaanxi, and Heilongjiang experiencing the highest decreases.

From Table 1, it can be seen that many 3-digit non-resource based industries are localized in Guangdong province. This is because foreign investment in the late 1980s and earlier 1990s was mainly from Hong Kong, Taiwan, and Macau, and the produce is either exported directly to other Asian countries or to the rest of the world through Hong Kong. Hence, the technology, design and quality of products have to comply with international standards. This makes Guangdong the unique location for these industries, such as bamboo, cane, palm fibre and straw products (204), plastic bags, packages and containers (305) and game equipment (245). Meanwhile, because of its easy access to new products

\footnotetext{
${ }^{10}$ The data are calculated from LBNICSC (1986) and TNICO (1996). This result is consistent with the results in the last section that most manufacturing industries were concentrated in coastal regions.
} 
in Hong Kong, some industries which mainly serve the domestic market are also localized in Guangdong, such as record pressing (232) and medical equipment (365).

While easy access to the world market and new technology has made Guangdong the home of many new export-oriented products, a historical advantage in production as well as the advantage of existing distribution channel for their products make Shanghai, Zhejiang, Jiangsu and Shandong main locations for some other manufacturing industries. As a leading region for both higher education and highly commercialised office blocks, Shanghai has a long history of producing high quality cultural goods (241), machines for cultural and office usage (425), and clocks (426). In the earlier 1980s, China introduced large chemical fibre production lines to Shanghai and Jiangsu due to their comparative advantage in related industries. This kind of investments kept Shanghai and Jiangsu's comparative advantages in these industries even up to 1995, when synthetic fibre (282) was localized in Shanghai and other textile (179) was localized in Jiangsu. Zhejiang province has many famous brands of tea which require both a unique baking technology and the particular tea tree leaves planted in this province. It also has special technology in wood products, especially red wooden furniture which is very popular in Hong Kong, Taiwan and Macau. Although foreign firms and joint ventures in red wooden furniture were also set up in Guangdong province in the 1990s, Zhejiang retained its leading place in both tea baking (155) and wood products (203) in 1995. Analogous to Zhejiang's situation, Shandong province has a comparative advantage in handcrafts and arts (431) and other tobacco processing (169).

According to New Economic Geography theory, labour mobility can facilitate both industrial agglomeration and industrial re-location. Although the existing household registration system limits legal permanent migration from rural to urban sectors and across regions, industrial concentration and agglomeration can be observed from the results of previous sections from 1985 to 1995. On the one hand, there are a large number of illegal migrants who can facilitate industrial agglomeration. On the other hand, substantial wage differences between regions, with a high average growth rate of real wage in coastal regions, have been observed by Ezakai and Sun (1999). This might be a 
result of industrial agglomeration, although the wage difference had not reversed the direction of industrial concentration up to 1995. However, as observed by Young (1997), inter-regional trade barriers would be a factor prohibiting further industrial agglomeration. For example, Zhejiang province used administrative measures to prevent other provinces from procuring silk cocoons from its farmers. And many regions now use registration measures (e.g. regulation on engine size for taxi registration) to limit the taxi industry to use cars produced locally.

\section{Determinants in the Location of Chinese Industry}

According to New Economic Geography theory (Krugman and Venable 1995, Fujita and Thisse 1996, Puga and Venable 1996, Fujita, Krugman and Venable 1999), firms locate in places where the market is large and the market is large where the firms locate as there is demand from downstream firms. More geographically concentrated production requires more workers and increases the population size in the region. When people live in close proximity, transportation costs incurred in the purchase and consumption of certain amount of goods are reduced and there will be agglomeration of transactions if the transportation or transaction costs are not negligible (Tabushi and Yoshida 2000, for example). However, increased wage and rent may encourage production dispersion when increased production costs outweigh the benefits of transaction agglomeration or the benefits of increasing returns to scale in production. To see what forces drive Chinese industrial concentration, this section tests the following hypotheses in an endeavour to find out the determinants of industrial concentration.

Hypothesis 1: Industry localizes in places where the market is large.

The size of a product market is determined by the definition of the product, the technologies used in producing different products and individual taste across different products given per capita income and homogenous consumers. If it is assumed that Chinese people in different regions have the same taste across different products, and all kinds of industrial products can be available to all regions at different transaction and transportation costs, the size of the local market of a region for all industrial products will 
increase with per capita income Ceteris Paribus. The size of the local market of a region for all industrial products will be larger the larger the population size Ceteris Paribus. The easier the access (cheaper) of a region to all industrial products, the larger the size of the local market. Hence, a region with better transportation connections to other regions will have a larger local market Ceteris Paribus. In the argument that industry locates in places where the market is large, 'market' refers to the local market. Hence, if hypothesis 1 is correct, the regional share in industrial GDP should be positively related to regional per capita GDP, its population size, and its transport connections to other regions.

\section{Hypothesis 2: The market is large where the industrial firms locate.}

Where industry locates, the regional share in industrial GDP is high. If the market is large where industry locates, a region with a higher share in industrial GDP should have a higher share in GDP.

As Smith (1776) expressed, the size of a market can be extended by transportation and communication networks through trade with other regions or exports. Hence, the regional share of industrial GDP should be higher the higher the export potential of the region Ceteris Paribus. As the export potential of a region is positively correlated to foreignrelated investment, the regional share of industrial GDP should also be positively correlated to foreign-related investment. As the new economic geography literature formally discusses how transportation costs affect industrial concentration, the writer formalizes the relationship between industrial concentration and transportation costs as the following hypothesis.

Hypothesis 3: Lower transaction and intra-regional transportation costs encourage industrial concentration while lower inter-regional transportation costs discourage industrial concentration.

It is difficult to obtain accurate data on the unit transaction and transportation costs in China. As cities usually have better infrastructure, such as legal system, transportation network and communication system which reduce transaction and transportation costs, the view can be taken that provinces with more cities should have better public 
infrastructure and thus higher unit transaction and transportation efficiency than provinces with less cities Ceteris Paribus, and hence, a higher share in industrial GDP if hypothesis 4 is correct. Since the 1980s, China has gained great support from many international financial institutions such as the World Bank in getting financial resources for the construction of high quality highways nationwide. Increased regional length of paved highways usually reduces inter-regional transportation costs, especially the transportation costs to nearby provinces. This reduction in transportation costs tends to discourage industrial concentration in certain provinces, although it may facilitate industrial agglomeration in several nearby provinces.

Hypothesis 4: Higher wage levels and price increases in industrial regions have not yet had a significant effect on industrial location.

Due to limited labour mobility in China, the wage rate and general price index are usually observed to be higher in regions where industry concentrated during the reform period. However, it can also be observed that most 2-digit industries became more geographically concentrated. Hence, it is likely that the wage and price differences in different regions had not become significant enough to generate impact on industrial localization.

1993 regional cross section data are used to test the above four hypotheses. As regional industrial GDP and total GDP are both endogeneous, the following system of equations is specified:

$$
\begin{aligned}
& S I Y=\beta_{0}+\beta_{1} y+\beta_{2} N+\beta_{3} A F I+\beta_{4} n c+\beta_{5} s p h w y+\beta_{6} s r w+\beta_{7} p i_{-1}+\beta_{8} a w_{-1}+\beta_{9} D \\
& S Y=\gamma_{0}+\gamma_{1} S I Y+\gamma_{2} N+\gamma_{3} A F I
\end{aligned}
$$

where $S I Y, S Y$ are the regional share in industrial GDP and total GDP, respectively. $y$ is per capita GDP and $N$ is population of the region. $A F I$ is investment in fixed assets of pure foreign units (including units of Hong Kong, Macau, and Taiwan entrepreneurs) and joint ventures. $n c$ is the number of cities in a region. sphwy and srw are the regional share in the total length of paved highways and the total length of operation railways, respectively. Although both sphwy and srw could capture the relative connectedness of 
one region to the other regions, the difference between them could be that srw may reflect long distance connection and, hence, potential extension of the market, while sphwy facilitates transportation to nearby regions by reducing transportation costs, and hence, may encourage industrial dispersion among nearby regions. $p i_{-1}$ is a variable reflecting price increase in the end of the previous year. It equals the price index of all retail sales in 1992 minus 100. $a w_{-1}$ is the average wage for each region in 1992. It equals total wage divided by employment. All data are drawn from the China Statistical Yearbook 1993 and 1994.

The population size of each region is treated as endogenous due to the household registration system. Although illegal migration follows the wage difference between regions in seeking higher earnings, official population data cannot significantly reflect this trend. In 1993, After Deng Xiaoping's South China tour in 1992, several economic laws were about to be passed. Then, the yearly investment in fixed capital relating to foreign and overseas Chinese ownership was stimulated from less than 1 per cent of total investment in fixed capital in 1992 to 8 per cent in 1993. In these early years of high levels of foreign direct investment, its destination was largely limited to SEZs and open coastal cities and was guided by the regional preferential policies. Hence, in the regression, $A F D I$ is also treated as exogenou. In addition, construction of infrastructure such as highways and railways are by and large under government planning, hence sphwy and $s r w$ are taken as exogenous as well. $p i_{-1}$ and $a w_{-1}$ are predetermined. A region dummy $D$ is used to distinguish Tianjing, Shanghai, Jiangsu, Zhejiang, Fujiang, Guangdong and Shandong provinces from other regions, as these regions are in close proximity to big ports for export. Given these exogenous and previous period variables, regional share in industrial GDP and regional per capita GDP are determined by the system of equations (2) simultaneously 11 The OLS estimation results are given in regression [1] in Table 3.

According to regression [1], the price increase and the average wage rate of the last year do not seem to significantly affect regional share in industrial GDP. Hence, hypothesis 4 cannot be rejected. Meanwhile, population size and investment in fixed assets of foreign-

\footnotetext{
${ }^{11}$ As $N$ is exogenous, $S Y$ is a monotonic increasing transformation of $y$.
} 
related units have a significant influence on regional share in industrial GDP, partly confirming that industry locates where the market is large. In addition, in regression [1], the regional share in GDP can be highly explained by the regional share in industrial GDP, regional population and investment in fixed assets of foreign related units. In fact, the correlation between the regional share in GDP and the regional share in industrial GDP is higher than 0.97. Hence, hypotheses 2 can be accepted. It was discussed earlier, that a railway system may extend a regional domestic market, but from the regression [1], this effect is not observed to be significant. According to Young (1997) and Amiti and Wen (forthcoming), there are strong inter-regional trade barriers in China. According to Kumar (1994), the average growth rate of inter-province trade was only about five per cent from 1985 to 1992, while the average growth rate of export value reached seventeen per cent during the same period. Finally, the number of cities as an indicator of regional transaction efficiency has a significant positive effect on regional share in industrial GDP. As expected, the relative length of pave highway has significant negative effect on regional share in industrial GDP. Therefore, lower intra-regional transportation and transaction costs encourage industrial concentration while lower inter-regional transportation costs discourage industrial concentration. Thus, hypothesis 3 can be accepted.

In regression [1], it seems that regional per capita GDP has no significant effect on industrial concentration. As stressed previously, population alone does not determine the size of a regional market. Instead, it is the purchasing power of a region that determines the local market size. Hence, per capita GDP should significantly affect industrial concentration. This effect was not observed in regression [1], as there are several insignificant explanatory variables in the regression. Meanwhile, per capita GDP is related to the regional share in GDP. Hence after dropping insignificant variables in the regression [1] and using instrumental variable approach to estimate each equation $(N, n c$, sphwy, srw and $D$ are used as instrumental variables), we obtain regression [2] as shown in Table 3. In regression [2], all the explanatory variables in the regional share in GDP equation are significant at 0.01 levels. In the equation of the regional share in industrial GDP, per capita GDP is significant at 0.05 level. Population and number of cities are 
significant at 0.01 levels. Yet, although $A F I$ is highly significant in the regional share in GDP, it becomes insignificant in the equation of regional share in industrial GDP after instrumental variables are used in the regression. Regression [2] shows that the positive effect of per capita GDP on regional industrial share is highly significant. Hence, per capita GDP and population size as different potentials of market size are determinants of industrial concentration. Thereby making hypothesis 1 acceptable. In addition, as regional number of cities has highly significant effect on regional share in industrial GDP, better infrastructure, which lowers intra-regional transaction and transportation costs, promotes industrial concentration, while lower inter-regional transportation costs, especially to nearby regions, may encourage industrial dispersion.

Is Increasing Return to Scale a Driving Force in the Agglomeration of Chinese Industry?

The above determinants of industrial concentration can be based on the agglomeration of transactions if there are no increasing returns to scale in production. However, increasing returns to scale in production is a main driving force of industrial agglomeration in the new economic geography literature. Due to the limited availability of data on capital stock, the panel data of 1980, 1984 and 1985 and the cross-section data of 1995 are used to establish industrial production functions respectively. The results are shown in Table 4 .

From Table 4, it can be seen that none of the explanatory variables in the translog production function are significant in both regressions and the Cobb-Douglas production provides a more reliable estimation in terms of the significance of explanatory variables and the adjusted R-squared. The F-tests on the sum of labor-output elasticity and capitaloutput elasticity in the Cobb-Douglas production function show that the null hypothesis that the industrial production exhibits constant returns to scale can be rejected but the null hypothesis that the sum of the labor-output elasticity and capital-output elasticity is equal to 1.17 cannot be rejected at the significance level of 0.15. Hence, in China, there are increasing returns to scale in industrial production, which is one of the driving forces of industrial agglomeration in the new economic geographical literature. 


\section{Policy Implications and conclusions}

It is evident that Chinese industry became more geographically concentrated following the economic reform. With preferential development policies, coastal provinces like Guangdong, Jiangsu and Shandong have become home to many manufacturing industries. As regional GDP is strongly correlated to regional industrial GDP, the localization of manufacturing industries accompanies with regional income disparity, which is widely observed ${ }^{12}$ and has recently become a main concern of the Chinese government.

Since the ninth five-year plan was formulated, the Chinese government has been trying to reduce regional income disparity. Measures taken include government investment for infrastructure improvement in the poorer regions, establishment of ten key projects for developing western regions in 2000, and favourable policies for foreign investment.

Regional share in GDP is positively related to regional market size and foreign related investment. Regional share in industrial GDP is positively related to regional market size. In addition, lower intra-regional transaction and transportation costs seem to facilitate industrial concentration. However, over the last two decades, the coastal regions have attracted foreign investment not only because of the preferential policies, but also due to their geographical proximity to big export ports. Hence, the effect of preferential policies in attracting foreign investment to the western regions would need to be different from the effect of the preferential policies given to the SEZ and open coastal cities in the 1980s. As the western regions have no geographical advantage in export, policies targeted at attracting or increasing foreign investment may succeed in industries whose produce mainly serves domestic, especially regional markets.

Due to the fact that Chinese industrial agglomeration is based on both transaction agglomeration, and production agglomeration with increasing returns to scale in

${ }^{12}$ See Ezaki and 1999, Wu 2000, for example. 
production, both labour force and capital are observed to move from the interior to the coastal provinces (Jian, Sachs and Warner, 1996). With limited mobility of factors, the increase in the regional general price index and the high wage rates in the industrial regions have not significantly affected industrial concentration. Hence, policies to increase factor mobility, such as abolishment of the household registration system, would further encourage industrial concentration and regional disparity.

The infrastructure improvement in poorer regions, the change in the population's attitudes towards doing business, and the increase in bureaucratic efficiency for improving transaction efficiency would encourage industrial concentration within these regions in the presence of the current regional trade barriers. However, this approach to the reduction of regional income disparity, compared with reducing regional trade barriers and encouraging regional specialization, would be at a high cost of economic efficiency based on the free location of industrial enterprises driven by economic forces such as economies of specialization, transaction agglomeration and increasing returns to scale in production. Therefore, the tradeoff between economic growth and regional equity has to be carefully weighed in the pursuit of policies to reduce regional disparity. 
Table 1 Locational Gini coefficients

\begin{tabular}{|r|l|c|c|c|}
\hline Code & Industry & Gini & $\begin{array}{c}\text { Highest } \\
\text { share } \\
\text { Province }\end{array}$ & Coastal \\
\hline 212 & $\begin{array}{l}\text { Bamboo, Cane, Palm Fibre and Straw } \\
\text { Products }\end{array}$ & 0.97 & GD & C \\
\hline 204 & Bamboo and Cane Furniture & 0.97 & GD & C \\
\hline 245 & Game equipment & 0.97 & GD & C \\
\hline 298 & Repair of rubber goods & 0.97 & GD & C \\
\hline 182 & Hats & 0.97 & JS & C \\
\hline 408 & Repair of electric machinery & 0.97 & LN & C \\
\hline 249 & Other Cultural, Educational and Sports & 0.97 & SH & C \\
\hline 251 & Goods & 0.97 & SX & \\
\hline 214 & Prtificial Crude Oil & 0.97 & YN & \\
\hline 295 & Regenerating rubber & 0.96 & SD & C \\
\hline 159 & Other Beverage & 0.95 & GD & C \\
\hline 136 & Salt Processing & 0.95 & JL & \\
\hline 232 & Record pressing & 0.95 & GD & C \\
\hline 169 & Other tobacco processing & 0.94 & SD & C \\
\hline 333 & Precious metal smelting & 0.91 & HEB & C \\
\hline 336 & Nonferrous metal alloy smelting & 0.91 & HUN & \\
\hline 241 & Cultural Goods & 0.91 & SH & C \\
\hline 219 & Other furniture & 0.90 & GD & C \\
\hline 189 & Other Fibre Products & 0.90 & JS & C \\
\hline 419 & Other electronic equipment & 0.89 & GD & C \\
\hline 161 & Baking of tobacco leaves & 0.89 & SD & C \\
\hline 435 & $\begin{array}{l}\text { Daily groceries (including mirror, glasses } \\
\text { and umbrellas) }\end{array}$ & 0.88 & SH & C \\
\hline 347 & $\begin{array}{l}\text { Metal surface processing and heat } \\
\text { processing }\end{array}$ & 0.88 & GD & C \\
\hline 299 & Other rubber products & 0.88 & HUB & \\
\hline 244 & Toys & 0.88 & JS & C \\
\hline 342 & Iron pipe casting & 0.87 & LN & C \\
\hline 243 & $\begin{array}{l}\text { Music instruments and other recreational } \\
\text { goods }\end{array}$ & 0.87 & YN & \\
\hline 306 & Plastic shoes & 0.87 & SC & \\
\hline 242 & Plastic bags, packages and containers & 0.86 & GD & C \\
\hline 253 & Sports goods & 0.86 & FJ & C \\
\hline & Petroleum products & LN & C \\
\hline
\end{tabular}




\begin{tabular}{|r|l|c|c|c|}
\hline 135 & Processing of aquatic products & 0.86 & SD & C \\
\hline 294 & Rubber parts & 0.86 & AH & \\
\hline 429 & Other instruments and meters & 0.86 & JS,SH & C \\
\hline 139 & Other food processing & 0.86 & SD & C \\
\hline 221 & Manufacturing of paper pulp & 0.85 & AN & \\
\hline 425 & Machine for cultural and office usage & 0.85 & SH & C \\
\hline 439 & Other groceries & 0.85 & ZH & C \\
\hline 274 & Animal medicine & 0.85 & SH & C \\
\hline 321 & Iron smelting & 0.85 & HEB & C \\
\hline 183 & Shoes & 0.85 & HEB & C \\
\hline 171 & Primary processing of raw fibre materials & 0.85 & SD & C \\
\hline 411 & Communications equipment & 0.84 & TJ & C \\
\hline 213 & Metal Furniture & 0.84 & GD & C \\
\hline 297 & Daily rubber products & 0.83 & HAIN & C \\
\hline 365 & Medical equipment & 0.83 & GD & C \\
\hline 155 & Tea baking & 0.83 & ZJ & C \\
\hline 179 & Other textile & 0.83 & JS & C \\
\hline 203 & Wood Products & 0.82 & ZJ & C \\
\hline 275 & Biological products & 0.82 & YN & \\
\hline 282 & Synthetic fibre & 0.82 & SH & C \\
\hline 368 & Repair of machinery and equipment for & 0.81 & HEB & C \\
\hline 285 & special purpose & & & \\
\hline 211 & Fishing equipment and fishing materials & 0.81 & GD & C \\
\hline 141 & Sweod Furniture & 0.81 & SD & C \\
\hline 152 & Soft Drinks & 0.80 & GD & C \\
\hline 308 & Plastic parts & 0.80 & GD & C \\
\hline 177 & Silk textile & 0.80 & ZJ & C \\
\hline 414 & Electronic computer & 0.80 & ZJ & C \\
\hline 266 & Synthetic materials & 0.79 & GD & C \\
\hline 413 & Broadcast and Television Equipment & 0.79 & LN & C \\
\hline 201 & Wood sawing and timber processing & 0.79 & BJ & C \\
\hline 309 & other plastic products & 0.79 & SH & C \\
\hline 191 & Leather & 0.79 & SD & C \\
\hline 193 & Fur softening and fur products & 0.78 & GS & \\
\hline 307 & Daily plastic grocery (including plastic & 0.78 & SH & C \\
\hline 145 & Fomb, plastic soap box, etc.) & GD & C \\
\hline & Container and Metal Packages & GD & C \\
\hline
\end{tabular}




\begin{tabular}{|r|l|c|c|c|}
\hline 304 & $\begin{array}{l}\text { Foaming plastic, man-made leather and } \\
\text { synthetic leather }\end{array}$ & 0.77 & GD,SD & C \\
\hline 257 & Coke refining & 0.77 & HEB & C \\
\hline 144 & Ferments & 0.77 & JL & \\
\hline 431 & Handcraft and arts & 0.77 & SD & C \\
\hline 281 & Fibrous Fibre & 0.76 & HEB & C \\
\hline 415 & Electronic device & 0.76 & SAX & \\
\hline 268 & Daily chemical products & 0.76 & GD & C \\
\hline 417 & Household electronic appliances & 0.76 & GD & C \\
\hline 426 & Clocks & 0.76 & SH & C \\
\hline 316 & Fire-resistant materials & 0.75 & LN & C \\
\hline 318 & Mineral fibre and its products & 0.75 & ZJ & C \\
\hline 406 & Household electric appliances & 0.75 & GD & C \\
\hline 374 & Bicycles & 0.75 & SH & C \\
\hline 195 & Down processing and feather products & 0.74 & ZJ & C \\
\hline 324 & Pressing and processing of steel & 0.74 & SH & C \\
\hline 423 & Electronic measure & 0.74 & SC & \\
\hline 302 & Plastic board, tube and bar materials & 0.74 & JS & C \\
\hline 292 & Tyre for man power driven carrier & 0.73 & FJ & C \\
\hline 133 & Sugar Processing & 0.73 & GD & C \\
\hline 317 & Graphite and carbon products & 0.73 & JL & \\
\hline 349 & Other metal products & 0.73 & SH & C \\
\hline 424 & Measures & 0.73 & JS & C \\
\hline 132 & Vegetable oil processing & 0.73 & GD & C \\
\hline 265 & Organic chemical products & 0.73 & JS,JL & \\
\hline 263 & Farm chemicals & 0.73 & JS & C \\
\hline 223 & Paper products & 0.72 & GD & C \\
\hline 319 & Other non-metal mineral products & 0.72 & JX & \\
\hline 359 & Other general machinery & 0.72 & SX & \\
\hline 181 & Garments & 0.72 & JS & C \\
\hline 407 & Lighting utensil & 0.71 & SH & C \\
\hline 331 & Heavy nonferrous metal smelting & 0.70 & GS & \\
\hline 373 & Motor cycles & 0.70 & SD & C \\
\hline 346 & Metal products for construction & 0.70 & HEB & C \\
\hline 334 & Rare and scarce metal smelting & 0.70 & HUN & \\
\hline 315 & Ceramic products & 0.69 & GD & C \\
\hline 202 & Ply Wood & GD & C \\
\hline 252 & Crude oil processing & HLJ & C \\
\hline 176 & Flax textile & & \\
\hline & & & & \\
\hline
\end{tabular}




\begin{tabular}{|c|c|c|c|c|}
\hline 142 & Dairy Products & 0.69 & ZJ,HB & $\mathrm{C}$ \\
\hline 409 & Other electric equipment & 0.69 & SH & $\mathrm{C}$ \\
\hline 376 & Ships & 0.69 & SH & $\mathrm{C}$ \\
\hline 293 & Rubber board tube and band & 0.68 & LN & $\mathrm{C}$ \\
\hline 348 & Daily metal products & 0.68 & GD & $\mathrm{C}$ \\
\hline 134 & $\begin{array}{l}\text { Slaughter and processing for meat and } \\
\text { eggs }\end{array}$ & 0.68 & SD & $\mathrm{C}$ \\
\hline 162 & Manufacturing of cigarette & 0.68 & YN & \\
\hline 357 & Casting and forging & 0.68 & $\mathrm{SH}$ & $\mathrm{C}$ \\
\hline 192 & Leather Products & 0.68 & JS & $\mathrm{C}$ \\
\hline 149 & Other Food Products & 0.68 & JS & $\mathrm{C}$ \\
\hline 345 & Metal thread, wire and their products & 0.67 & JS & $\mathrm{C}$ \\
\hline 422 & Apparatus and meters for special usage & 0.66 & JS & $\mathrm{C}$ \\
\hline 322 & Steel making & 0.65 & BJ & $\mathrm{C}$ \\
\hline 291 & Tyre & 0.65 & SD & $\mathrm{C}$ \\
\hline 303 & $\begin{array}{l}\text { Plastic thread, string and the knitted } \\
\text { products }\end{array}$ & 0.65 & SD & $\mathrm{C}$ \\
\hline 174 & Wool textile & 0.65 & JS & $\mathrm{C}$ \\
\hline 356 & Other general parts and components & 0.65 & JS & $\mathrm{C}$ \\
\hline 338 & Pressing of nonferrous metals & 0.64 & JS & $\mathrm{C}$ \\
\hline 372 & Motor vehicle & 0.64 & $\mathrm{JL}$ & \\
\hline 341 & Metal Frameworks & 0.63 & JS & $\mathrm{C}$ \\
\hline 353 & General equipment & 0.63 & $\mathrm{SH}$ & $\mathrm{C}$ \\
\hline 364 & $\begin{array}{l}\text { Machines for agriculture, forestry, animal } \\
\text { husbandry, fishery, and irrigation }\end{array}$ & 0.63 & SD & $\mathrm{C}$ \\
\hline 363 & $\begin{array}{l}\text { Special equipment for light industry and } \\
\text { textile industry }\end{array}$ & 0.62 & SH & $\mathrm{C}$ \\
\hline 178 & Knitted textile & 0.62 & SH & $\mathrm{C}$ \\
\hline 326 & Iron alloy smelting & 0.62 & $\mathrm{JL}$ & \\
\hline 416 & Electronic parts & 0.62 & JS & $\mathrm{C}$ \\
\hline 371 & Railway equipment & 0.62 & HEB & $\mathrm{C}$ \\
\hline 314 & Glass and glass products & 0.61 & GD & $\mathrm{C}$ \\
\hline 351 & Boiler and motive power machinery & 0.61 & JS & $\mathrm{C}$ \\
\hline 301 & Plastic film & 0.61 & GD & $\mathrm{C}$ \\
\hline 143 & Canned Food Products & 0.61 & ZJ & $\mathrm{C}$ \\
\hline 404 & Materials for electric work & 0.61 & JS & $\mathrm{C}$ \\
\hline 312 & $\begin{array}{l}\text { Cement products and asbestos cement } \\
\text { products }\end{array}$ & 0.60 & $\mathrm{SH}$ & $\mathrm{C}$ \\
\hline 271 & Original chemical medicine & 0.60 & HEB & $\mathrm{C}$ \\
\hline 401 & Electric engine & 0.60 & GD & $\mathrm{C}$ \\
\hline 296 & Rubber boots & 0.60 & JS & $\mathrm{C}$ \\
\hline
\end{tabular}




\begin{tabular}{|r|l|c|c|c|}
\hline 421 & General apparatus and meters & 0.59 & SH & C \\
\hline 313 & Tile, lime and light building materials & 0.59 & BJ & C \\
\hline 343 & Tools & 0.59 & SH & C \\
\hline 332 & Light nonferrous metal smelting & 0.58 & GZ & \\
\hline 361 & $\begin{array}{l}\text { Special equipment for metallurgy, mine } \\
\text { and electric machinery }\end{array}$ & 0.58 & LN & C \\
\hline 402 & $\begin{array}{l}\text { Transmission provisions and control } \\
\text { equipment for electricity }\end{array}$ & 0.58 & JS & C \\
\hline 378 & Repair of Transport Equipment & 0.57 & GD & C \\
\hline 273 & $\begin{array}{l}\text { Processing of raw Chinese medical herbs } \\
\text { and Chinese Pharmaceutical }\end{array}$ & 0.57 & GD & C \\
\hline 354 & Bearing and valve & 0.57 & LN & C \\
\hline 362 & $\begin{array}{l}\text { Special equipment for petro-chemistry \& } \\
\text { other industries }\end{array}$ & 0.57 & JS & C \\
\hline 262 & Chemical Fertilizer & 0.56 & HEB,SD, & \\
\hline 367 & Equipment for other special usage & 0.54 & LN,SH & C \\
\hline 222 & Papermaking & 0.54 & SD & C \\
\hline 172 & Cotton textile & 0.54 & JS & C \\
\hline 231 & Printing industry & 0.52 & SH & C \\
\hline 151 & Alcohol and Wine & 0.52 & SD & C \\
\hline 272 & Chemical medicine preparation & 0.52 & TJ & C \\
\hline 311 & Cement & 0.52 & GD & C \\
\hline 131 & Grain and forage processing & 0.51 & JS,GD & C \\
\hline 261 & Basic Raw Chemical Materials & 0.51 & SD & C \\
\hline 267 & Chemical products for special usage & 0.50 & JS & C \\
\hline 352 & Metal processing machinery & 0.45 & JS & C \\
\hline & & & & \\
\hline
\end{tabular}

Note: The names of the thirty regions are abbreviated in this table as follows: Anhui---AH, Beijing---BJ, Fujian---FJ, Gansu---GS, Guangdong---GD, Guangxi--GX, Guizhou---GZ, Hainan--HAIN, Hebei---HEB, Heilongjiang---HLJ, Henan--HEN, Hubei---HUB, Hunan---HUN, Inner Mongolia---IM, Jiangsu---JS, Jiangxi--JX, Jilin---JL, Liaoning---LN, Ningxia---NX, Qinghai---QH, Shandong---SD, Shanghai---SH, Shaanxi---SAX, Shanxi---SX, Sichuan---SC, Tianjin---TJ, Tibet--TB, Xinjiang---XJ, Yunnan---YN, Zhejiang---ZJ

This table is reproduced from Amiti and Wen (forthcoming). 
Table 2 A Historical Comparison of Industrial Concentration (Gini) and Regions with the Highest and the Second Highest Industrial Shares

\begin{tabular}{|c|c|c|c|c|c|c|}
\hline Industry & GINI95 & RHSH95 & GINI85 & RHSH85 & GINI80 & RHSH80 \\
\hline $\begin{array}{l}\text { Logging and Transport of } \\
\text { Wood and Bamboo }\end{array}$ & 0.793 & HLJ, JL & 0.777 & HLJ, JL & 0.75 & HLJ, JL \\
\hline $\begin{array}{l}\text { Cultural, Educational and } \\
\text { Sports Goods }\end{array}$ & 0.756 & GD, JS & 0.696 & $\mathrm{SH}, \mathrm{GD}$ & 0.712 & $\mathrm{SH}, \mathrm{BJ}$ \\
\hline \begin{tabular}{|l} 
Electronic and \\
Communications Equipment
\end{tabular} & 0.701 & GD, JS & 0.584 & JS, SH & 0.593 & SH, JS \\
\hline $\begin{array}{l}\text { Garments and Other Fiber } \\
\text { Products }\end{array}$ & 0.692 & GD, JS & 0.473 & $\mathrm{SH}, \mathrm{JS}$ & 0.446 & $\mathrm{SH}, \mathrm{JS}$ \\
\hline Chemical Fiber & 0.684 & JS, SH & 0.667 & $\mathrm{SH}, \mathrm{JS}$ & 0.72 & $\mathrm{SH}, \mathrm{JS}$ \\
\hline $\begin{array}{l}\text { Leather, Fur, Feather and } \\
\text { Manufaacturing of Leather, } \\
\text { Fur and Feather Products }\end{array}$ & 0.666 & GD, ZJ & 0.405 & JS, SH & 0.405 & $\mathrm{SD}, \mathrm{SH}$ \\
\hline $\begin{array}{l}\text { Electric Equipment and } \\
\text { Machinery }\end{array}$ & 0.644 & GD, JS & 0.525 & $\mathrm{SH}, \mathrm{JS}$ & 0.509 & SH, LN \\
\hline Textile & 0.641 & JS, ZJ & 0.554 & JS, SH & 0.555 & SH, JS \\
\hline Plastic Products & 0.63 & GD, JS & 0.526 & JS, ZJ & 0.513 & JS, SH \\
\hline $\begin{array}{l}\text { Instruments, Meters, } \\
\text { Cultural and Office } \\
\text { Machinery }\end{array}$ & 0.629 & GD, SH & 0.549 & SH, JS & 0.554 & SH, JS \\
\hline Metal Products & 0.596 & JS, GD & 0.479 & $\mathrm{SH}, \mathrm{JS}$ & 0.477 & $\mathrm{SH}, \mathrm{JS}$ \\
\hline Furniture & 0.547 & GD, SD & 0.414 & GD, JS & 0.388 & GD, SD \\
\hline Tobacco Processing & 0.542 & YN, HUN & 0.485 & HEN, YN & 0.483 & HEN, SD \\
\hline Rubber Products & 0.536 & $\mathrm{SD}, \mathrm{SH}$ & 0.447 & $\mathrm{SH}, \mathrm{SD}$ & 0.469 & $\mathrm{SH}, \mathrm{SD}$ \\
\hline Transport Equipment & 0.534 & $\mathrm{SH}, \mathrm{JS}$ & 0.473 & HUB, LN & 0.477 & LN, HUB \\
\hline $\begin{array}{l}\text { Smelting and Pressing of } \\
\text { Ferrous Metal }\end{array}$ & 0.525 & $\mathrm{SH}, \mathrm{LN}$ & 0.557 & LN, SH & 0.579 & LN, SH \\
\hline Non-metal Mineral Products & 0.513 & JS, GD & 0.413 & JS, LN & 0.415 & JS, LN \\
\hline $\begin{array}{l}\text { Processing of Wood and } \\
\text { Manufacturing of Bamboo, } \\
\text { Cane, Palm and Straw } \\
\text { Products }\end{array}$ & 0.495 & GD, JS & 0.461 & HLJ, SH & 0.485 & HLJ, SH \\
\hline $\begin{array}{l}\text { Paper Milling and } \\
\text { Manufacturing of Paper } \\
\text { Products }\end{array}$ & 0.493 & GD, SD & 0.407 & $\mathrm{~N}, \mathrm{SH}$ & 0.411 & LN, SH \\
\hline $\begin{array}{l}\text { Raw Chemical Material and } \\
\text { Chemical Products }\end{array}$ & 0.492 & JS, GD & 0.451 & JS, SH & 0.459 & $\mathrm{SH}, \mathrm{JS}$ \\
\hline $\begin{array}{l}\text { Printing and Record Media } \\
\text { Reproduction }\end{array}$ & 0.49 & GD, JS & 0.413 & $3 \mathrm{~J}, \mathrm{SH}$ & 0.393 & $\mathrm{BJ}, \mathrm{SH}$ \\
\hline $\begin{array}{l}\text { Medical and } \\
\text { Pharmaceutical products }\end{array}$ & 0.485 & JS, GD & 0.448 & $\mathrm{SH}, \mathrm{JS}$ & 0.461 & $\mathrm{SH}, \mathrm{JS}$ \\
\hline Beverage Manufacturing & 0.475 & GD, SD & 0.423 & SC, ZJ & 0.429 & ZJ, SD \\
\hline Food Manufacturing & 0.472 & $\mathrm{SD}, \mathrm{GD}$ & 0.376 & JS, SC & 0.362 & JS, GD \\
\hline $\begin{array}{l}\text { Smelting and Pressing of } \\
\text { Nonferrous Metal }\end{array}$ & 0.433 & JS, GD & 0.476 & $\mathrm{SH}, \mathrm{LN}$ & 0.532 & SH, LN \\
\hline
\end{tabular}


Table 3 Determinants of Industrial Concentration

\begin{tabular}{|c|c|c|c|c|}
\hline \multirow{2}{*}{$\begin{array}{l}\text { Dependent } \\
\text { variables } \\
\begin{array}{l}\text { Explanatory } \\
\text { variables }\end{array}\end{array}$} & \multicolumn{2}{|c|}{ Regional share in industrial GDP } & \multicolumn{2}{|c|}{ Regional share in GDP } \\
\hline & Regression [1] & Regression [2] & Regression [1] & Regression [2] \\
\hline $\begin{array}{l}\text { Constant } \\
\left(\beta_{0}, \gamma_{0}\right)\end{array}$ & $\begin{array}{l}-0.009 \\
(0.0096)\end{array}$ & $\begin{array}{c}-0.023^{*} \\
(0.011)\end{array}$ & $\begin{array}{l}1.08 \mathrm{E}-04 \\
(1.20 \mathrm{E}-03)\end{array}$ & \\
\hline $\begin{array}{l}\text { Share in indus- } \\
\text { trial GDP }(S I Y)\end{array}$ & & & $\begin{array}{c}0.60^{* * * *} \\
(0.053)\end{array}$ & $\begin{array}{l}0.509^{* * *} \\
(0.095)\end{array}$ \\
\hline $\begin{array}{l}\text { Per capita GDP } \\
\qquad(y)\end{array}$ & $\begin{array}{l}3.22 \mathrm{E}-06 \\
(2.50 \mathrm{E}-06)\end{array}$ & $\begin{array}{l}2.12 \mathrm{E}-05^{* * *} \\
(8.53 \mathrm{E}-06)\end{array}$ & & \\
\hline $\begin{array}{l}\text { Population } \\
\qquad(N)\end{array}$ & $\begin{array}{c}4.89 \mathrm{E}-06^{* * *} \\
(1.51 \mathrm{E}-06)\end{array}$ & $\begin{array}{c}4.60 \mathrm{E}-06^{* * *} \\
(1.46 \mathrm{E}-06)\end{array}$ & $\begin{array}{l}2.41 \mathrm{E}-06^{* * *} \\
(3.75 \mathrm{E}-07)\end{array}$ & $\begin{array}{c}2.67 \mathrm{E}-06^{* * *} \\
(4.86 \mathrm{E}-07)\end{array}$ \\
\hline $\begin{array}{l}\text { Investment in } \\
\text { fixed assets of } \\
\text { foreign-related } \\
\text { units }(A F D I)\end{array}$ & $\begin{array}{l}2.08 \mathrm{E}-04^{* * *} \\
(8.51 \mathrm{E}-05)\end{array}$ & $\begin{array}{l}1.72 \mathrm{E}-04 \\
(1.66 \mathrm{E}-04)\end{array}$ & $\begin{array}{l}1.61 \mathrm{E}-04^{* * * *} \\
(3.29 \mathrm{E}-05)\end{array}$ & $\begin{array}{l}2.46 \mathrm{E}-04^{* * *} \\
(6.94 \mathrm{E}-05)\end{array}$ \\
\hline $\begin{array}{l}\text { Number of } \\
\text { cities }(n c)\end{array}$ & $\begin{array}{c}9.09 \mathrm{E}-04^{* * * *} \\
(3.64 \mathrm{E}-04)\end{array}$ & $\begin{array}{c}1.20 \mathrm{E}-03^{* * *} \\
(3.89 \mathrm{E}-04)\end{array}$ & & \\
\hline sphwy & $\begin{array}{l}-0.35^{* *} \\
(0.17)\end{array}$ & $\begin{array}{l}-0.264 \\
(0.184)\end{array}$ & & \\
\hline$s r w$ & $\begin{array}{l}0.07 \\
(0.13)\end{array}$ & & & \\
\hline $\begin{array}{l}\text { Price increase } \\
\text { in the last year } \\
(p i)\end{array}$ & $\begin{array}{c}-4.82 \mathrm{E}-04 \\
(1.46 \mathrm{E}-03)\end{array}$ & & & \\
\hline $\begin{array}{l}\text { Average wage } \\
\text { rate of last year } \\
(a w)\end{array}$ & $\begin{array}{c}4.21 \mathrm{E}-03 \\
(0.099)\end{array}$ & & & \\
\hline $\begin{array}{l}\text { Region Dummy } \\
\text { (D) }\end{array}$ & $\begin{array}{l}9.84 \mathrm{E}-03 \\
(6.33 \mathrm{E}-03)\end{array}$ & & & \\
\hline Adjusted $\mathrm{R}^{2}$ & 0.90 & 0.90 & 0.98 & 0.98 \\
\hline
\end{tabular}

Note: (1) The numbers in brackets are standard errors.

$(2)^{*},{ }^{* *}$ and ${ }^{* * *}$ indicate significance higher than 0.100 .05 and 0.01 levels, respectively. 
Table 4 Industry Production Function

\begin{tabular}{|c|c|c|c|c|}
\hline \multirow{2}{*}{$\begin{array}{l}\text { Dependent } \\
\text { variables } Y \\
\begin{array}{l}\text { Explanatory } \\
\text { variables }\end{array}\end{array}$} & \multicolumn{2}{|c|}{$\begin{array}{l}\text { Panel Data of Year } 1980,1984 \text { and } \\
1985 \text { from the } 2^{\text {nd }} \text { Industrial } \\
\text { Census }\end{array}$} & \multicolumn{2}{|c|}{$\begin{array}{l}\text { Regional Cross-section Data of } \\
1995 \text { from the } 3^{\text {rd }} \text { Industrial } \\
\text { Census }\end{array}$} \\
\hline & Translog & Cobb-Douglas & Translog & Cobb-Douglas \\
\hline Constant & $\begin{array}{l}-0.985 \\
(28.347)\end{array}$ & $\begin{array}{l}3.919^{* * *} \\
(0.996)\end{array}$ & $\begin{array}{l}-1.225 \\
(2.989)\end{array}$ & $\begin{array}{c}-1.666^{* * *} \\
(0.321)\end{array}$ \\
\hline $\log K$ & $\begin{array}{l}1.380 \\
(5.912)\end{array}$ & $\begin{array}{c}0.377^{* * * *} \\
(0.103)\end{array}$ & $\begin{array}{l}1.135 \\
(2.650)\end{array}$ & $\begin{array}{c}0.943^{* * *} \\
(0.158)\end{array}$ \\
\hline $\log L$ & $\begin{array}{l}0.014 \\
(5.035)\end{array}$ & $\begin{array}{l}0.799^{* * *} \\
(0.091)\end{array}$ & $\begin{array}{l}-0.165 \\
(2.222)\end{array}$ & $\begin{array}{l}0.221 \\
(0.147)\end{array}$ \\
\hline$(\log K)^{2}$ & $\begin{array}{l}-0.052 \\
(0.309)\end{array}$ & & $\begin{array}{l}-0.269 \\
(0.643)\end{array}$ & \\
\hline$(\log L)^{2}$ & $\begin{array}{l}-0.037 \\
(0.238)\end{array}$ & & $\begin{array}{l}-0.345 \\
(0.561)\end{array}$ & \\
\hline$(\log K)(\log L)$ & $\begin{array}{l}0.083 \\
(0.534)\end{array}$ & & $\begin{array}{l}0.062 \\
(1.175)\end{array}$ & \\
\hline Adjusted- $R^{2}$ & 0.96 & 0.96 & 0.976 & 0.978 \\
\hline $\begin{array}{l}\text { F-test on } \\
\mathrm{c}(2)+\mathrm{c}(3)=1 \mathrm{in} \\
\text { Cobb-Douglas } \\
\text { Function Form }\end{array}$ & & 37.37 & & 23.31 \\
\hline $\begin{array}{c}\text { F-test on } \\
\mathrm{c}(2)+\mathrm{c}(3)=1.17\end{array}$ & & 0.039 & & 0.034 \\
\hline
\end{tabular}

Note: (1) The numbers in brackets are standard errors.

(2) ${ }^{* * *}$ indicate significance higher than 0.01 levels. Estimates without ${ }^{* * *}$ are not significant even at 0.10 levels.

(3) Due to limited data, in the panel data regression, output is the net output value of all industrial enterprises. Labor input is the average number of employees within the year of all industrial enterprises and capital input is the net value of the fixed assets of all industrial enterprises. In the cross-section regression, output, labor and capital inputs are value-added, number of employees and net value of fixed assets of all independent industrial accounting units at or above town level as the capital stock of all industrial enterprises is not available. 


\section{References}

Amiti, M. (1998), "New Trade Theories and Industrial Location in the EU: A Survey of Evidence", Oxford Review of Economic Policy, 14(2), 45-53.

Amiti, M. and M. Wen (forthcoming), "Spatial Distribution of Manufacturing in China", in Modelling the Chinese Economy, ed. by P. Lloyd and X. Zhang, London: Edward Elgar.

Development Research Center of the State Council (DRCSC for abbreviation) (1992), China: Urban Development Towards the Year 2000, Shenyang: the People's Publishing House of Laioning (in Chinese).

Ezaki, M. and L. Sun (1999), "Growth Accounting in China for National, Regional, and Provincial Economies: 1981-1995”, Asian Economic Journal, 13(1), 39-71.

Fujita, M.and J.-F. Thisse (1996), "Economies of Agglomeration." Journal of Japanese and International Economies, 10, 339-78.

Fujita, M. and P. Krugman (1995), "When is the economy monocentric?: von Thünen and Chamberlin unified," Regional Science and Urban Economics, 25, 505-28.

Fujita, M., Krugman, P. and A.J. Venables (1999), The Spatial Economy: Cities, Regions and International Trade, Cambridge and London: MIT Press.

Jian, T, Sachs J. and A.Warner (1996), "Trends in Regional Inequality in China", China Economic Review, 7(1), 1-21.

Krugman, P. (1991), "Increasing Returns and Economic Geography”, Journal of Political Economy, 99, 483-499.

Krugman, P. and A.J. Venables (1995), "Globalization and the Inequality of Nations", Quarterly Journal of Economics, 110(4), 857-80.

Kumar, A. (1994), "China: internal market development and regulation," World Bank Country Study, Washington DC: The World Bank.

Puga, D. and A.J. Venables (1996), “The Spread of Industry: Spatial Agglomeration in Economic Development," Journal of Japanese and International Economies, 10(4), 440-464.

The Leading Body of National Industrial Census of the State Council ( LBNICSC for abbreviation) (1986), The Data of the 1985 Industrial Census of the People's 
Republic of China, Volume 4 (regional Volume), Beijing: China Statistical Publishing House.

Smith, Adam (1776), Wealth of Nations, Aldine Press, J.M.Dent \& Sons Ltd, 1970.

The State Statistics Bureau of the PRC (1993-1994), Statistical Yearbook of China, China Statistical Publishing House, Beijing. (1994), China Statistical Yearbook of Industrial Economy, China Statistical Publishing House, Beijing.

Tabuchi, T. and A. Yoshida (2000), "Separating Urban Agglomeration Economies in Consumption and Production", Journal of Urban Economics, 48, 70-84.

The Third National Industrial Census Office (TNICO for abbreviation) (1996), The Organization and Implementation of the Third National Industrial Census, Beijing: China Statistical Publishing House.

The Third National Industrial Census Office (1997), The Data of the Third Industrial Census of the People's Republic of China in 1995, Regional Volume, Beijing: China Statistical Publishing House.

Young, Alwyn (1997), "The Razor's Edge: Distortions and Incremental Reform in the Peoples' Republic of China," unpublished mimeo, Boston University. 